\title{
Important Plant Areas of the Peri-North Tien Shan Subprovince as Perspective Protection Areas of Phytobiodiversity
}

\author{
G. M. Kudabayeva, P. V. Vesselova, M. P. Danilov, B. M. Sultanova \\ Institute of Botany \&Phytointroduction Ministry of Education and Science, Almaty, Kazakhstan
}

\section{Email address:}

kgm_anita@mail.ru (G. M. Kudabayeva),pol_ves@mail.ru (P. V. Vesselova), michaelpetrovich@mail.ru (M. P. Danilov), sultanovab@mail.ru (B. M. Sultanova)

\section{To cite this article:}

G. M. Kudabayeva, P. V. Vesselova, M. P. Danilov, B. M. Sultanova. Important Plant Areas of the Peri-North Tien Shan Subprovince as Perspective Protection Areas of Phytobiodiversity. American Journal of Environmental Protection. Special Issue: Applied Ecology: Problems, Innovations. Vol. 4, No. 3-1, 2015, pp. 123-129. doi: 10.11648/j.ajep.s.2015040301.29

\begin{abstract}
This article describes the identification results of Important Plant Areas within the Peri-Tien Shan botanicgeographic sub-province. It was shown that identification of Important Plant Areas for Kazakhstan territory is the crucial tool for conservation of botanic diversity as well as rare, endemic and relic species. The results of the survey and their compliance with the criteria were shown by the example of three among 32 detected important areas. The botanic value of areas and their phytocoenotic diversity were demonstrated. The rare, endemic and relic species of each area were recorded.
\end{abstract}

Keywords: Important Plant Areas, Peri-North Tien Shan Botanic-Geographic Sub-Province, Floristic, Phytocoenotic Diversity

\section{Introduction}

Considering the significance of biodiversity conservation, Kazakhstan has signed and ratified global ecological conventions [1,2]. With the aim to comply with the convention obligations, Kazakhstan has developed the National strategy and action plan aimed at conservation and balanced use of biodiversity [3].

In 2002, the Global strategy of plant conservation developed at the $6^{\text {th }}$ Conference of Convention Parties in the Hague was accepted. It was recommended to develop the regional and national strategies of plant conservative, which would consider the specifics of regions.

In Kazakhstan the environment is under active, pressing which affects the number of natural components of biocoenosis or even leads to extinction of certain species. Considering that it is a continuing process, the development of biodiversity conservation measures and first of all, rare flora specimens are of particular actuality.

Kazakhstani species requiring protection (rare, endemic and relic species) are provided in the Red Data Book of Kazakhstan [4]. If their number in the first edition was 308, then in the List of rare and endangered species of fauna and flora their number amounted to more than 387 species. This points to the fact that it is necessary to conduct additional measures aimed at detection of location areas of rare species as well as their plant communities for further possibility of conservation.

The issue of necessity to detect the most Important Plant Areas for the purpose of their further conservation was proclaimed in 1995 at the first pan-European plant conservation conference of Planta Europa in Hyeres (France). Consequently, the criteria for identification of Important Plant Areas (IPA) were developed and the terminology was defined. By 2007, the lists of IPA were prepared for the most countries of Central, East and Southern Europe. In CIS countries this work was done in Belarus (2007), partly for Ukraine and Armenia [7], Uzbekistan.

For the purpose of identification of the most valuable areas, the methods implemented within the framework of the project "Important Plant Areas of Central and East Europe" (2002-2004) were developed. In Russia, the strategy of important areas at the regional level was developed within the framework of the project "Strategy of plant conservation of Altay-Sayan Ecoregion" as well as in separate regions $[8,9]$.

The purposeful study for identification of Important Plant 
Areas within Kazakhstan were not conducted. However, the experience obtained during the preparation of the Regional State Cadastre of plants of certain regions of Kazakhstan (East Kazakhstan, Aktobe, South Kazakhstan, Mangistau, Zhambyl and Kzylorda) and regional Red Data Books is available.

In addition, the detailed up-to-date layout of botanicgeographic zoning [10] was compiled for desert areas of Kazakhstan which in fact can be used further as the basis for creation of IPA network, whereas methodologically it will allow identifying IPA with account of not only floristic diversity but also regularities of composition of vegetation cover.

Overall, the important areas can consequently be involved in the evaluation process of SPNA network and detection of their gaps. However, it should be noted that IPA is not a specific kind of protected area, but is the most important tool for efficiency checking of already existing SPNA within Kazakhstan.

\section{Study Area \& Methods}

Preliminarily conducted works have determined the necessity to develop the project «Important Plant Areas of Kazakhstan - monitoring basis of vegetation status (by the example of the Peri-North Tien Shan botanic-geographic subprovince)» aimed at possibility to detect areas characterized by high botanic value.

The selection of piedmont plains of Tien Shan as a model area was stipulated by a number of factors. First of all, it should be noted that these areas represent ecotone (transitional) cross-pollinated strip whose floristic composition combines the elements of desert plains and mountain ecosystems. In addition, piedmont plains of subprovince are densely populated and are intensely used in agriculture (plough land, pasture) and industry. As a result of the combined negative impact of man-made factors on natural ecosystems and first of all, on their vegetation component it was recorded that the composition and structure of vegetation cover have simplified across all areas. Namely, at these areas, it is necessary to detect and conserve natural areas having a high degree of biodiversity. The important argument for the study of piedmont areas consists in unique species composition having a high degree of endemism as well as availability of relics and threatened species.

Given that regional ecosystem of the Peri-North Tien Shan subprovince is intensely impacted, this area is covered insufficiently with the network of Specially Protected Natural Areas (SPNA) while in hard-to-reach mountains this network in the form of nature reserves and national parks is dense enough. Our work aimed at the study of IPA may fill in the gap in regard to environmental protection. Certain areas are perspective for establishment of new SPNA.

Survey targets are Important Plant Areas of piedmont plains included in the composition of the Peri-North Tien
Shan botanic-geographic subprovince within piedmont plains of the North Tien Shan. Important plant area means natural or semi-natural area with high botanic diversity and (or) area which maintains the unique community of rare, threatened species and (or) endemic species of plants and (or) plant community of high botanic value [6].

Survey methods: common floristic, geobotanic, cartographic.

During the identification of Important Plant Areas, the developed criteria were used:

A - availability of threatened species within the area:

$A(i)$ - plant species, under the threat of global extinction;

$A($ ii) - plant species under the threat of extinction in

Europe;

A(iii) - endemic endangered species listed in the National Red Data Book and not included in A(i) or A(ii);

$A(i v)$ - endangered subendemic narrowly-areal species not included in A(i) or A(ii) and spread in adjacent countries;

$A(v)$ - rare, endangered and protected species.

B - overall high species richness of flora or richness in plant species having any particular importance;

$\mathrm{C}$ - availability of endangered habitats in the area.

\section{Results \&Discussion}

Overall, 32 IPAs were identified within the Peri-North Tien Shan botanic-geographic subprovince of the total area 13321 ha. The criteria developed by EUNIS and adapted for Altay-Sayan Ecoregion (Russia) were used during the identification of Important Plant Area. The area of identified plots in each case is unique taking into account specific conditions.

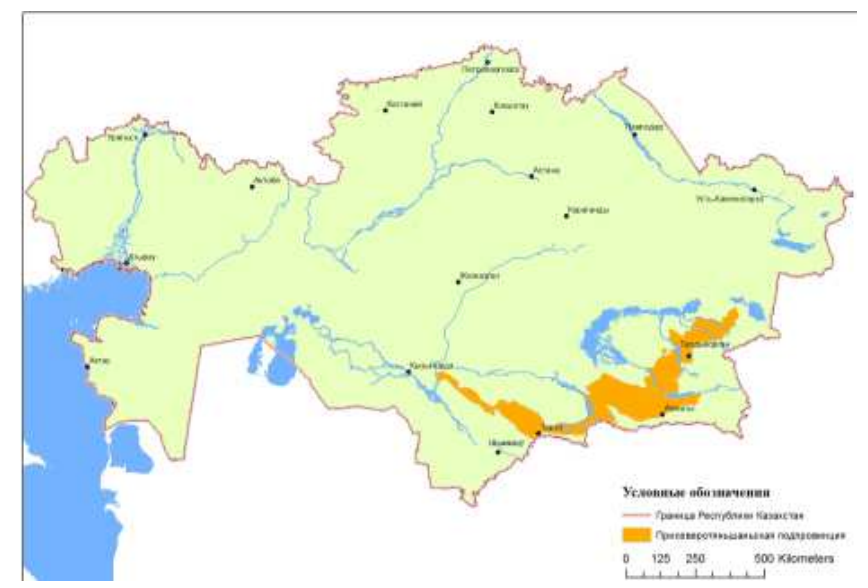

Figure 1. Layout of Peri-North Tien Shan botanic-geographic subprovince

The area of the Peri-North Tien Shan botanic-geogrpahic subprovince occupies piedmont plains of Tien Shan (piedmonts of Zailiyskiy Alatau, Chu-Iliyskiy mountains, Dzhungarian Alatau, Karatau).

Among the most important identified botanic areas are Tyrnakty mountain area (Chu-Iliyskiy mountains), Azat (Zailiyskiy Alatau), Samsy (Zailiyskiy Alatau piedmonts). 


\subsection{Important Plant Area - Tyrnakty (Chu-Iliyskiy mountains)}

Location: Almaty region, Zhambyl district. Coordinates: $\mathrm{N}$ $43^{\circ} 52^{\prime} 13,4^{\prime \prime}$ E $075^{\circ} 21 ' 53,5^{\prime \prime}$. Absolute elevation 1070-1092 m. Area - 371 ha.

Proposed Tyrnakty IPA refers to the piedmont plain of Chu-Iliyskiy mountains. Site elevation ranges within 1070$1092 \mathrm{~m}$ above MSL. Terrain relief is gently-rugged plain with intersteeply-sloping depressions intersected by the branches of temporary water channels. Water regime is automorphous and semi-terrestrial characterized by seasonal atmospheric and additional surface moistening of the area.

According to botanic-geographic zoning [10], vegetation cover of Tyrnakty IPA is referred to Peri-North Tien Shan piedmont subprovince, Dzhungarian-North Tien Shan province, Iran-Turan subregion, Sakhara-Gobi desert area. V.N. Khramtzov [11] has referred the Chu-Iliyskiy mountains to botanic-geographic type of the Peri-North Tien Shan semishrubs (Artemisia heptapotamica, A. sublessingiana) deserts with grass plants (Stipa richterana, S. sareptana). The intrinsic components of these phytocoenoses are ephermers (Alyssum turkestanicum, Taeniatherum crinitum, Anisantha tectorum, Eremopyrum orientale, Trigonella arcuata) and ephemeroids (Poa bulbosa, Gagea olgae, Eremurus inderiense, Tulipa kolpakovskiana). Floristic diversity of Tyrnakty IPA is represented by 52 species of vascular plants.

In the allocated site Niedzwedzkia semiretschenskia B. Fedtsch., which is the only representative of the family Bignoniaceae Juss. in natural flora of Kazakhstan, was noted. Niedzwedzkia semiretschenskia is the rarest endemic, highly decorative species of monotype order growing only in the South Kazakhstan in the east part of Chu-Iliyskiy mountains.

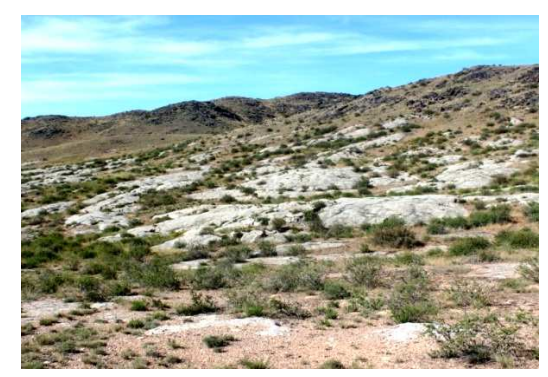

Figure 2. General view of Tyrnakty IPA

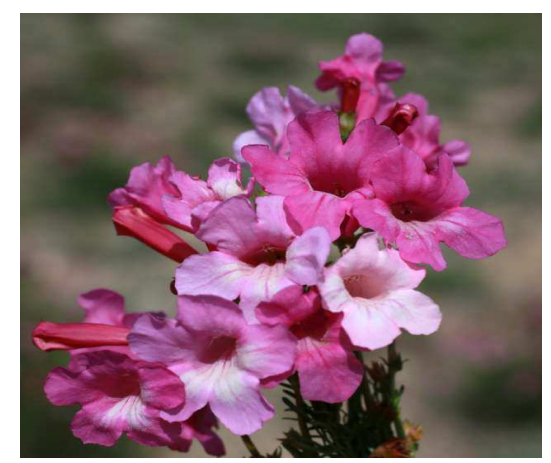

Figure 3. Flowering specimens of Niedzwedzkia semiretschenskia B. Fedtsch.
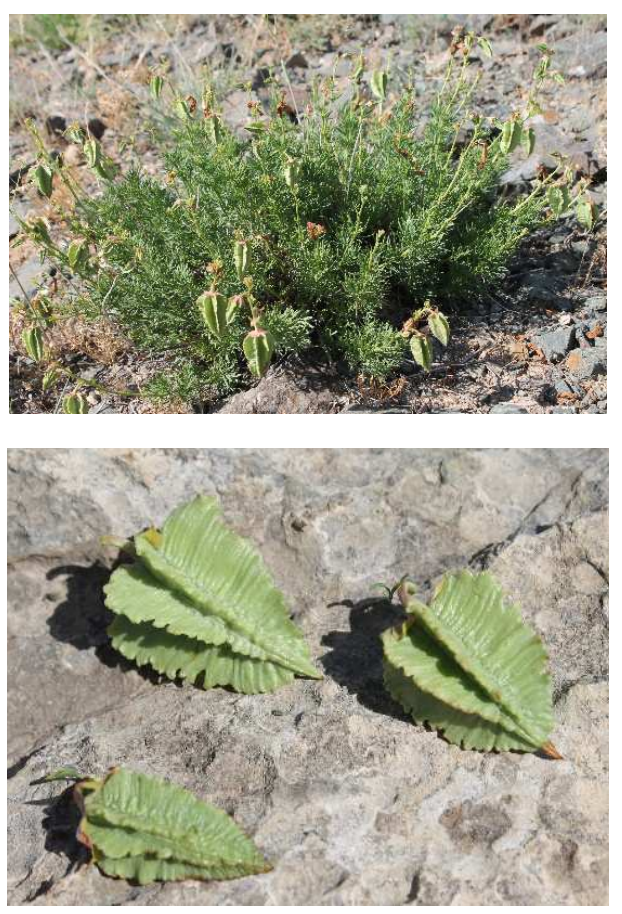

Figure 4. Fruit-bearing specimens of Niedzwedzkia semiretschenskia B. Fedtsch.

The species is included in the Red Data Book [4] of Kazakhstan. As to its taxonomic status, there are different opinions. According to Grierson understanding, this species is referred to Incarvillea Juss. order - Incarvillea semiretschenskia (B. Fedtsch.) Grierson [12]. However, in the survey work of V.V. Fisyun [13], based on comparative analysis of fruit structure, endosperm development, pollen morphology, availability of sticky glands, it can be concluded with certainty that this species is regarded as self-consistent order Niedzwedzkia, which is of high priority and complies with original description of B. Fedchenko. Uniqueness of morphological features as reproductive organs (fruit - sixwinged ligneous capsule) as well as a life form (plant with multiple stems lignifying at the bottom), geographic hiatus with other family representatives (Himalaya and Pamir-Altay) are indicative of long-term duration of establishment period of this relic taxon. According to evidence of Kamelin R.V. [14] «there is no such possibility to date precisely its age, but there is no doubt that its age is significant, but not younger than Miocene age and it is most likely older». In addition, he thinks that "mesophilic and thermophilic character of the flora of their arising and long-term evolution in-situ in conditions of low competence and increasing xerophilization" contributed significantly to the establishment of this species. At present, this species has legal conservation status embodied in the List of rare and threatened species of flora and fauna [5], in the materials of the Republican Red Data Book [4]. However, the areal of this species does not fall within the protected area (although it is located nearby) of historic-cultural and nature reservemuseum "Tanbalytas" (included in the list of UNESCO World Heritage site, whereas the main function is to conserve archeological monument and petroglyphs [15]. The species 
grows at sloping, stony-rubbly hillsides, sloping tops located within the strip of intensified pasturing thus causing real threat to conservation of relic species. The data of I.I. Kokoreva et al. [16] are indicative of significant reduction of floristic and phytocoenotic diversity of communities with Niedzwedzkia semiretschenskia due to increase of anthropogenic impact.

In addition, two species listed in the Red Data Book were recorded within proposed IPA: Juno kuschakewitsczii, Juno caerulea. Likewise, three species of tulips were encountered within Tyrnakty IPA [4, 15, 16, 17, 18,] listed in the Red Data Book of Kazakhstan. Among them are Albert tulip (Tulipa alberti) - rare, endemic species, Greig tulip (Tulipa greigii) rare, endemic species with contracting areal and Regel tulip (Tulipa regelii) - rare, threatened, endemic species.

Concentration of rare, relic and endemic species included in the National Red Data Book allows to identify this area as an Important Plant Area. It is necessary to carry out the protective measures as the loss of such unique botanic objects is irreplaceable.

\subsection{Important Plant Area - Azat (Piedmont and North Part of High Foothills of Zailiyskiy Alatau Northeastwards of Talgar Town)}

Location: Almaty region, Talgar district. Coordinates: N $43^{\circ} 20^{\prime} 33.4^{\prime \prime}$ and E $077^{\circ} 16^{\prime} 36.4^{\prime \prime}$. Absolute elevation - $1044 \mathrm{~m}$. Area - 112 ha.

IPA is located at the transition boundary North Tien Shan and Peri-North Tien Shan botanic-geographic subprovinces. Elevation point ranges within 1100-900 m above the sea level. The landscape is a deeply cut valley of the temporary waterway of the eastern slope of the high foothills, that adjoins to the alluvial loss into the piedmont plain.

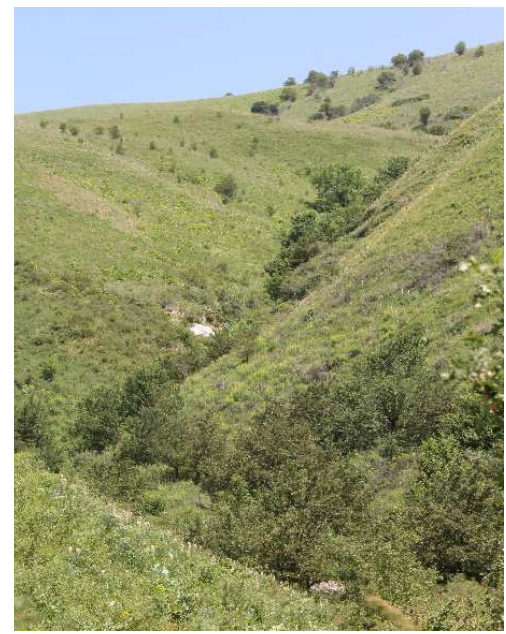

Figure 5. General view of Azat IPA

Vegetation cover is quite diverse [19]. At the bottom of ravines and at the lower parts of north slopes, the brushwood of high shrubs with parts of wild fruit forests are spread. The structure of tree and shrubbery vegetation includes high shrubs and low trees such as Berberis sphaerocarpa, Crataegus songarica, Malus sieversii, Frangula alnus. The lower tier is occupied by Lonicera altmannii, Rosa alberti, Spiraea hypericifolia, Euonymus semenovii, Rubus idaeus. The grass tier is represented by Aegopodium tadshikorum, Agrimonia asiatica, Artemisia dracunculus, Brachypodium sylvaticum, Dictamnus angustifolius, Eremurus robustus, Euphorbia lamprocarpa, Festuca gigantea, Geum urbanum, Impatiens parviflora, Leonurus turkestanicus, Ligularia heterophylla, Origanum vulgare, Poa nemoralis etc. Iris sogdiana is often encountered at the bottom of ravines. Species abundance of tree and shrubbery communities often exceeds 50 species per $100 \mathrm{~m}^{2}$.

The semi-dominant dry meadows and meadow steppes are common on north slopes and forest fringes of tree and shrubbery vegetation, including Brachypodium pinnatum, Bromopsis inermis, Dactylis glomerata, Elymus tianschanigenus, Phleum phleoides, Poa angustifolia. Such species are intrinsic among the representatives of wild grasses as Achillea millefolium, Betonica foliosa, Bunium setaceum, Hypericum perforatum, Inula macrophylla, Paeonia anomala, Potentilla impolita, Vicia tenuifolia etc.

Shrub and meadow-mesophilic communities are surrounded by ephemeroid-grassy-sagebrush communities at loessial slopes of ridgy low-hill terrains. Along with the representatives of desertified and dry steppes (Artemisia sublessingiana, Poa bulbosa, Festuca valesiaca, Kochia prostrata, Stipa sareptana), including associated ephemeroids (Crocus alatavicus, Gentiana olivieri, Holosteum umbellatum, Geranium transversale, Iridodictyum kolpakowskianum and etc.), large ephemeroids and wild grasses can be encountered in these communities which are intrinsic to semi-savannas of southernmost regions of Central Asia such as Crambe kotschyana, Elytrigia trichophora, Eremurus tianschanicus, Scabiosa songarica and etc. Xerophilic shrubs like Cerasus tianschanica, Ephedra equisetina, Rosa platyacantha can be encountered by south slopes.

The botanic value of the area consists in big phytocoenotic diversity. Among vegetation communities there dominates phytocoenosis with high level of floristic richness. Flora includes endemic species of Zailiyskiy Alatau included in the National Red Data Book [4]: Atraphaxis muschketovii, Erysimum croceum, Tulipa ostrowskiana. Tertiary relicts of broad-leaved forests are present in tree and shrubbery vegetation which are common with South Siberia taiga [10] Brachypodium sylvaticum, Festuca gigantea, Geranium robertianum.

At Azat IPA, 109 species of higher vascular plants were recorded among which there are 16 species of trees and shrubs. The representatives of forests, shrubs, meadows, deserts and Middle Asia savanna-growing species are present in ecological spectrum.

As consistent with the criterion A(iii), ten threatened species listed in the Red Data Book of Kazakhstan were recorded within IPA [4]: Armeniaca vulgaris, Atraphaxis muschketovii, Malus sieversii, Crocus alatavicus, Erysimum croceum, Gymnospermium altaicum, Iridodictyum kolpakowskianum, Tulipa kolpakowskiana, Tulipa 
ostrowskiana.

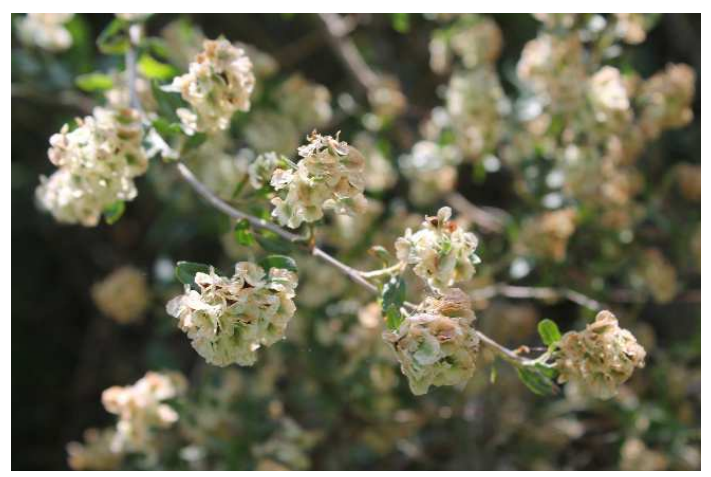

Figure 6. Atraphaxis muschketovii

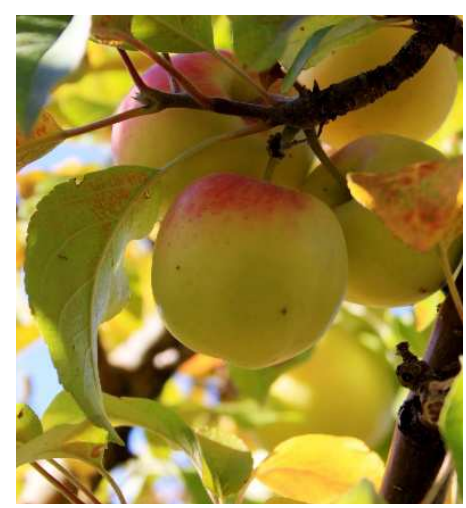

Figure 7. Malus sieversii

The high level of floristic richness with significant participation of rare and endemic species (criteria B) is intrinsic to IPA. Flora include a wide range of botanicgeographic elements. A big diversity of multispecies vegetation communities was recorded at loesses and bouldercobble deposits of high and low piedmonts within the studied area (criteria $\mathrm{C}$ ).

The area is frequently used for pasturing. The main part of vegetation cover is assessed as background. However, the ecosystem undergoes a significant transformation. The alien to local flora species like Ulmus pumila and Ulmus laevis were encountered among brushwood of trees and shrubs. The brushwood of quarantine weeds Pseudosophora alopecuroides occupy large areas.

The state of rare and threatened species is satisfactory. The degree of anthropogenic impact varies from weak to strong.

Unfortunately, the piedmonts of Almaty region are protected improperly by the network of Specially Protected Natural Areas (SPNA) - reserves and SNNP. SPNA occupies the main areas in middle and high altitudes. There is an acute need to protect vegetation cover of piedmonts by including them in SPNA or by the creation of a specific botanic nature reserve that may include such areas as Azat IPA.

\subsection{Important Plant Area - the Samsy River Valley (Piedmonts of Zailiyskiy Alatau)}

Location: Almaty region, Zhambyl district. Coordinates: $\mathrm{N}$ $43^{\circ} 15^{\prime} 12.1^{\prime \prime}$ and E $076^{\circ} 06^{\prime} 28.3^{\prime \prime}$. Absolute elevation - $888 \mathrm{~m}$.
Area - 74 ha.

Samsy IPA is located within piedmonts of the west part of Zailiyskiy Alatau. Elevation points range within 1000-800 m above the sea level.

Terrain relief is low mountain, hummocky-steeply-sloping, dissected by the channels of temporary water streams and complicated by ridges with outcrops of conglomerates of boulder-cobble deposits. The landscape of hummocky piedmonts smoothly runs into sloping piedmont plain.

The ephemeroid-sagebrush vegetation communities such as Artemisia sublessingiana, Carex pachystylis, Poa bulbosa, Festuca valesiaca, Kochia prostrata, Stipa sareptana intrinsic to piedmonts of Zailiyskiy Alatau are prevalent at the area. At the beginning of vegetation period and in the first half of summer, the numerous ephemers and ephemeroids such as Anemone gortschakowii, Ceratocephala testiculata, Crocus alatavicus, Eremurus altaicus, Gagea ova, Gentiana olivieri, Holosteum umbellatum, Geranium transversale, Iridodictyum kolpakowskianum and etc. play a significant role in vegetation structure. The sparse petrophyte grouping including representatives of Juno order is encountered at the outcrops of wind-blown conglomerates. Along temporary water courses and river banks there are brushwood of shrubs and meadows. High altitude-zonal location contributes to a big diversity of ephemers and ephemeroids in vegetation cover.

Floristic diversity at Samsy IPA includes 48 species of higher vascular plants whose majority consists of ephemers and ephemeroids adapted to Mediterranean regime of atmospheric precipitations with their maximum in spring.

Phytocoenotic structure and flora composition of IPA is in large measure determined by the composition of underlying mountain rocks - boulder-cobble conglomerates cemented by carbonate mortar which can be accounted for encountering of Juno almaatensis, species which was earlier regarded as extinct.

Juno almaatensis was first described byacademician N.V. Pavlov. However, the available herbarium specimens did not retain the color of the crown - one of the main systematic feature of taxon. A.I. Vvedenskiy was doubtful of this species as to its pertaining to individual order, considering that it may represent the diversity of another junona species. However, during a number of years, the specimens of this species were not encountered at the place where they first had been described. The taxon was regarded as lost in the area of their natural habitat. In 2009, A.A. Ivaschenko [20] found the specimens having the intrinsic green color of the crown near v. Samsy. These specimens were found at geographically another places, although ecological conditions of growth were similar to typical. During field surveys aimed at identification of IPA, not only the specimens Juno almaatensis were again collected in the outskirts of v. Samsy but also the area of taxon growth was expanded.

When analyzing species of Junona order of North Tien Shan, I.I. Kokoreva [16] has traced a number of morphological consequently changing transition forms having a certain similarity with the description of Juno 
almaatensis. It is necessary to continue studying this taxon in order to identify its systematic status.

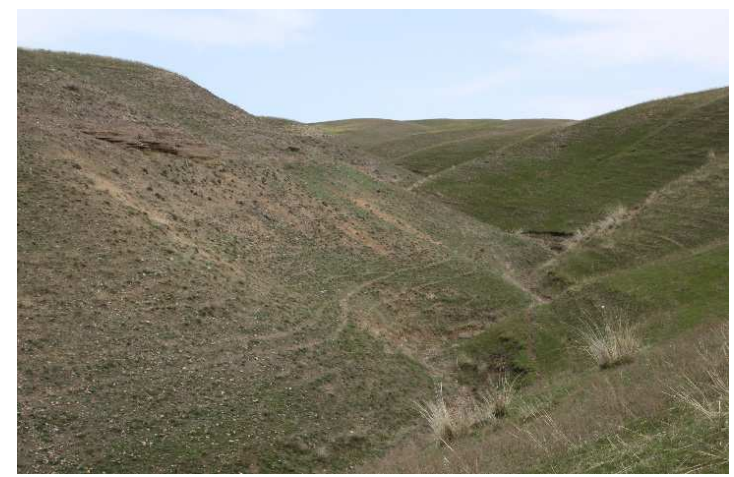

Figure 8. General view of Samsy IPA

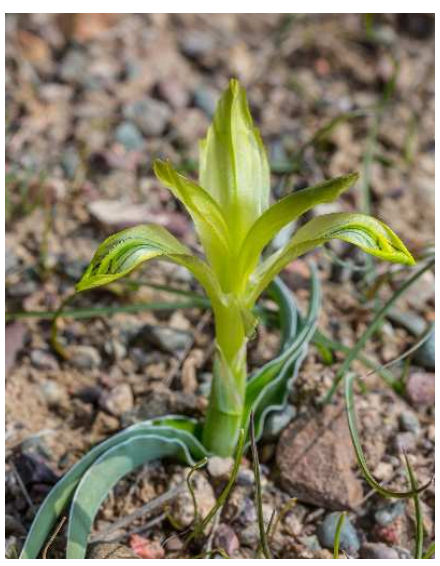

Figure 9. Juno almaatensis

One of substantiations for IPA identification was growth of other rare flora species. Five threatened endemic species listed in the National Red Data Books were recorded within the territory of proposed Samsy IPA (criteria A(iii) [4]: Crocus alatavicus, Iridodictyum kolpakowskianum, Juno almaatensis, Juno kuschakewiczii, Tulipa kolpakowskiana. It should be pointed out to exclusive participation of ephemers and ephemeroids (criteria B) in flora richness. The outcrops of conglomerates and their wind-blown rock slides and alluvial deposits with groupings of petrophytes are of certain interest.

The territory is often used for pasturing. The main part of vegetation cover of the territory is assessed as background with spots of minor degree disturbance. Among the types of anthropogenic impact are pasturing, roads, steppe fires. The degree of anthropogenic impact is transitional ranging from minor to moderate.

On the basis of identified IPA, the botanic nature reserve should be arranged in order to protect ephemers and ephemeroids, particularly for narrowly distributed endemic species Juno almaatensis.

\section{Conclusion}

Considering the vastness of Kazakhstan territory as well as necessity to carry out the inventory works for localization of botanic diversity, the work implemented for identification of Important Plant Areas within Peri-North Tien Shan botanicgeographic subprovince is the initial phase for creation of IPA network. In the following, the database of Important Plant Areas representing reserve fund of the Republic gene pool will be created.

Identification of Important Plant Areas within Kazakhstan territory is the crucial tool for conservation of botanic diversity as well as rare, endemic and relic species. Selection of piedmont areas (taking into account peculiarities of floristic composition and man-made impact in the region) as an object for IPA identification is topical for the possibility to make decisions on their conservation.

Currently, 32 IPAs identified within Peri-North Tien Shan botanic-geographic subprovince are not included in the system of Specially Protected Natural Areas (SPNA) of Kazakhstan. However, they are characterized by a high degree of species diversity and species, both listed in the Red Data Book of Kazakhstan and endemic species grow in these areas.

Proposed areas (Tyrnakty, Azat, Samsy) are characterized by the richness of species composition. The flora composition includes unique relic species as well as rare, narrowly-endemic species. For the purpose of conservation of unique objects, part of surveyed areas were recommended to be put under protection status.

The results of works aimed at identification of Important Plant Areas within Kazakhstan territory were approved at $7^{\text {th }}$ Conference Planta Europa «Plants for people, people for plants» (Crete, 2014).

\section{References}

[1] Convention on Biological Diversity (in Russian) (1995). Switzerland, $34 \mathrm{p}$.

[2] UN Convention to Combat Desertification (1994). Paris, 66 p.

[3] National Strategy and Action Plan on conservation and balanced use of biodiversity (1999). Almaty, $336 \mathrm{p}$.

[4] KazSSR Red Data Book (1981). Alma-Ata, V. 2, 263 p.

[5] Resolution of the RoK Government. On approval of the List of rare and threatened species of flora and fauna: approved as of $31^{\text {st }}$ October, 2006, No.1034.

[6] Sh. Anderson, Identification of Important Plant Areas. Guidelines on selection of IPAs in Europe and development basis of these rules for other world regions (2003). M., 39 p.

[7] I.I. Artemov, A.Yu. Korolyuk, N.N. Laschinskiy, I.E. Smelyanskiy, Identification criteria for Important Plant Areas in Altay-Sayan ecoregion (2007). Novosibirsk: Siberian Ecological center, $106 \mathrm{p}$.

[8] Important Plant Areas of Kemerovo region (2009). Kemerovo, $112 \mathrm{p}$.

[9] I.A. Boriskin, O.D. Chernova, E.A. Bondarevich, Identification of Important Plant Areas of south-east of Zabaikalskiykrai (2011). // Proceedings of $2^{\text {nd }}$ International Internet Conference. Kazan, pp. 22-27. 
[10] Botanic geography of Kazakhstan and Central Asia (within desert area) (2003). St.Petersburg, $423 \mathrm{p}$.

[11] V.N. Khramtzov, Piedmont deserts // Botanic geography of Kazakhstan and Central Asia (within desert area) (2003). St.Petersburg, pp. 157-166.

[12] Rare and threatened species of USSR Flora requiring protection (1981). L.: Science, 262 p.

[13] V.V. Fisyun, Materials on systematics and ecology of Niedzwedzkiasemirechenskaya // Botanic herbaria materials of AS KazSSR Institute of Botany (1982). Alma-Ata, No.12, pp. 49-57.

[14] R.V. Kamelin, On generic endemism of Central Asia Flora (1965) // Botanic magazine, V. 50, No. 12, p. 1708.

[15] O.V. Marynich, S.A. Nigmatova, Valuable botanic objects of historic-cultural and nature reserve-museum "Tamgaly" (2005)
// Botanic surveys in Kazakh Altay. Ridder, pp. 145-148.

[16] I.I. Kokoreva, I.G. Otradnykh, I.A. Syedina, V.V. Lysenko, Rare plant species of North Tien Shan (2013). Almaty, 208 p.

[17] Kazakhstan Flora (1956-1966). Alma-Ata, V. 1-9.

[18] A.A. Ivaschenko, Kazakhstan tulips (2005). Almaty, 192 p.

[19] P.V. Veselova, G.M. Kudabayeva, S.K. Mukhtubayeva, Peculiarities of floristic composition of communities of piedmont Peri-North Tien Shan deserts (2012)// Vegetable world and its protection. Almaty, pp.31-34.

[20] A.A. Ivaschenko, O.V. Belyalov, New finding of Junonaalmatinskaya (Juno almatensisPavl.) (2009)// Terra magazine, No. 1(9), pp. 58-63/ 